\section{Scientific journal}

PHYSICAL AND MATHEMATICAL EDUCATION

Has been issued since 2013.

Науковий журнал

ФІЗИКО-МАТЕМАТИЧНА ОСВІТА

Видається з 2013.
ISSN 2413-158X (online)

ISSN 2413-1571 (print)

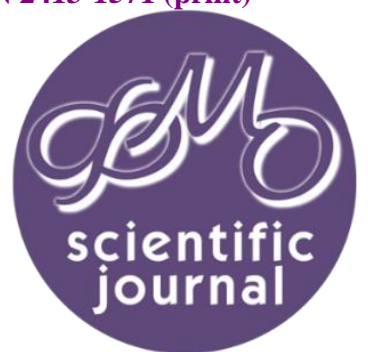

Плотнікова О.Л., Коробова І.В. Реалізація трансдисциплінарного підходу у процесі формування природничоматематичної компетентності майбутніх моряків. Фізико-математична освіта, 2021. Випуск 5(31). С. 67-72.

Plotnikova O., Korobova I. Implementation of transdisciplinary approach as a means of formation of natural and mathematical competence of future seamen. Physical and Mathematical Education, 2021. Issue 5(31). P. 67-72.

DOI 10.31110/2413-1571-2021-031-5-010

УдК 37.01/.09

О.л. Плотнікова

Херсонський морський коледж рибної промисловості, Україна plalleon69@gmail.com https://orcid.org/0000-0002-4306-4616

I.B. Коробова

Херсонський державний університет, Україна irinakorobova8@gmail.com https://orcid.org/0000-0003-2653-277X

\title{
РЕАЛІЗАЦІЯ ТРАНСДИСЦИПЛІНАРНОГО ПІДХОДУ \\ У ПРОЦЕСІ ФОРМУВАННЯ ПРИРОДНИЧО-МАТЕМАТИЧНОЇ КОМПЕТЕНТНОСТІ МАЙБУТНІХ МОРЯКІВ
}

\section{АНОТАЦІЯ}

Формулювання проблеми. Сучасна українська освіта перебуває на етапі реформування. Перенасичення ринку праці фахівцями гуманітарного напряму не сприяє активному розвитку економічної галузі нашої країни. Саме тому Міністерство освіти і науки України зміщує акценти з дисциплін гуманітарної спрямованості на дисципліни природничоматематичного циклу. При цьому у процесі професійної діяльності фахівці усіх галузей (у тому числі й морської) стикаються з проблемами, вирішення яких потребує міждисциплінарних знань, тобто, їм необхідно проявити свою компетентність. Основою підготовки таких фахівців вважається впровадження в освітній процес трансдисциплінарного підходу, який на сьогодні є необхідною умовою розвитку освіти в цілому. Окрім цього, реалізація трансдисциплінарного підходу надає можливість активізувати пізнавальну діяльність здобувачів, сприяє формуванню в них професійних якостей, зокрема, природничо-математичної компетентності.

Метою статті є аналіз особливостей трансдисциплінарного підходу та виявлення можливостей його реалізації в процесі формування природничо-математичної компетентності майбутніх моряків.

Матеріали й методи. В роботі використані теоретичні й емпіричні методи дослідження, такі як аналіз літературних джерел, синтез, спостереження за освітнім процесом, систематизація й узагальнення результатів дослідження.

Результати. У роботі наведено приклад компетентнісного завдання, сконструйованого у межах трансдисциплінарного підходу. Досвід використання компетентнісних завдань у процесі навчання майбутніх моряків засвідчив їх ефективність, оскільки вони надають широкі можливості залучення майбутніх фахівців до розв'язування практичних проблем, наближених до професійної діяльності майбутніх моряків, що у свою чергу, сприяє формуванню їх природничоматематичної компетентності.

Висновки. Доведено, що трансдисциплінарний підхід є актуальним на сьогодні і дає широкі можливості викладачам для досягнення поставлених цілей освітнього процесу. Окрім того, що трансдисциплінарний підхід є необхідною умовою розвитку сучасної освіти, він також є запорукою успішного формування природничо-математичної компетентності майбутніх моряків, яка передбачає уміння здобувача проявити набуті інтегровані знання з математики, фізики та інформатики у процесі вирішення професійних завдань. Одним із шляхів реалізації трансдисциплінарного підходу в освітньому процесі є залучення здобувачів до розв'язання компетентнісних задач.

кЛЮчОвІ СлОвА: трансдисциплінарний підхід, природничо-математична компетентність, компетентнісне завдання, освітній процес.

\section{ВСТУП}

На сьогодні українська освіта перебуває на етапі модернізації та реформування, що суттєво впливає на якість підготовки фахівців різного профілю. При цьому з'являються чимало освітніх напрямків та інноваційних освітніх продуктів, що підтверджується досвідом роботи провідних вчених та практиків. Паралельно зі змінами в освітній галузі відбуваються

(С О.Л. Плотнікова, І.В. Коробова, 2021. 
зміни і у суспільстві - перехід на новий інформаційний рівень. У таких умовах (різноманіття педагогічних концепцій, підходів та продуктів, а також інформатизація всіх галузей суспільства) виникають труднощі у підготовці майбутніх фахівців, морського профілю зокрема. Підготовка майбутніх фахівців морського профілю - це складний педагогічний процес, який передбачає формування у курсантів не тільки професійної, але й інших видів компетентностей, що дає можливість їм виконувати свої професійні обов'язки на високому рівні. Вирішення зазначених проблем можливе за умов впровадження в освітній процес трансдисциплінарного підходу, який привертає значну увагу не тільки українських, але й зарубіжних учених. Реалізація зазначеного підходу дає змогу здійснити інтеграцію знань здобувачів освіти морського профілю та підвищити їх професійний рівень.

Метою статті $\epsilon$ аналіз особливостей трансдисциплінарного підходу та виявлення можливостей його реалізації в процесі формування природничо-математичної компетентності майбутніх моряків. Завдання, що були розв'язані у зв'язку з поставленою метою:

- зіставлення понять «міждисциплінарність» та «трансдисциплінарність», виявлення особливостей трансцисциплінарнгого підходу;

- визначення поняття «природничо-математична компетентність» та аналіз ії структури;

- розробка компетентнісного завдання на засадах трансдисциплінарного підходу та його методичний аналіз.

\section{МЕТОДИ ДОСЛІДЖЕННЯ}

Предметом дослідження є основні засади трансдисциплінарного підходу до організації освітнього процесу, а також формування природничо-математичної компетентності майбутніх судноводіїв і судномеханіків. у роботі використані теоретичні та емпіричні методи дослідження, зокрема аналіз літературних джерел, синтез, спостереження за освітнім процесом, систематизація й узагальнення результатів дослідження.

\section{РЕЗУЛЬТАТИ ДОСЛІДЖЕННЯ ТА ЇХ ОБГОВОРЕННЯ}

Аналіз наукової літератури засвідчив, що актуальним на сьогодні в освіті є міждисциплінарний підхід, який надає можливість одночасно вирішити низку завдань: методологічні, організаційні та інформаційні (Кушнір, 2018). Однак, не зважаючи на значні переваги міждисциплінарного підходу, у сучасних умовах глобалізації науки більш актуальною $\epsilon$ інтеграція окремих дисциплін, що сприяє виникненню нового знання. Саме з цим пов'язана поява нових підходів, зокрема, трансдисциплінарного.

Питання впровадження трансдисциплінарного підходу в освітній процес знайшло відображення у роботах як вітчизняних, так і зарубіжних науковців. Результати їх аналізу засвідчили відсутність єдиного визначення понять «міждисциплінарність» та «трансдисциплінарність», що обумовлює проблему їх зіставлення, а в деяких випадках і їх ототожнення. Зокрема, німецький дослідник Ю.Міттельштрасс дотримується думки, що трансдисциплінарність тотожна міждисциплінарності, а основне завдання трансдисциплінарності полягає у подоланні дисциплінарних прогалин (Mittelstraß, 2000). У своїх доробках Л.Киященко та В.Моісеєв, вказуючи на відмінність між трансдисциплінарністю та міждисциплінарністю, зазначають, що «ситуація міждисциплінарності - це ситуація перенесення знання з однієї дисциплінарної області в іншу при збереженні дисциплінарних поділів. Тобто, міждисциплінарність методологічно додатково збагачує те, що визначено всередині дисциплінарних поділів. Ситуація трансдисциплінарності передбачає порушення жорсткості дисциплінарних поділів наукового знання» (Киященко\&Моісеєв, 2009). Розвиток трансдисциплінарної парадигми у сучасному освітньому просторі висвітлений у Рекомендаціях ЮНЕСКО, де зазначено, що основним методом вирішення проблем у XXI столітті $\epsilon$ саме трансдисциплінарний підхід. При цьому автори Рекомендацій стверджують, що доцільно «заохочувати трансдисциплінарні програми навчального процесу і вчити майбутніх фахівців використовувати трансдисциплінарний підхід при розв'язанні складних проблем природи та суспільства» (UNESCO, 1998).

На думку А.Савкова, інтеграція певних інтелектуальних ресурсів конкретних дисциплін у межах трансдисциплінарності передбачає не тільки поєднання знань, які є запозиченими з різних дисциплін, але й передбачає створення міждисциплінарного освітнього простору, в якому виробляється новий продукт. При цьому нові знання не втрачають зв'язку та спорідненості із тими дисциплінами, з яких вони попередньо були отримані (Савков, 2018). Розглядаючи трансдисциплінарність як одну з можливостей отримання нових знань, С.Ганаба зазначає, що трансдисциплінарні знання $є$ знаннями проблемними, оскільки дають можливість не лише розв'язувати практичні завдання, а й відображають здатність їх продукувати (Ганаба, 2014). Узагальнюючи підходи вчених з питання впровадження трансдисциплінарного підходу в освітній процес, можна стверджувати, що серед дослідників відсутня єдність щодо визначення поняття "трансдисциплінарний підхід", проте більшість науковців вважають, що зазначений підхід $є$ необхідною умовою розвитку освіти та особистості, оскільки передбачає зростання як інтелектуального ресурсу, так і розвиток особистості; реалізує проблемний характер навчання - здобувачі розглядають одну проблему з різних позицій, тобто шукають декілька підходів до її розв'язання; дає можливість розкрити складну природу суб'єктів освітньої взаємодії, а також складність освітнього процесу; надає можливість розв'язувати поставлені завдання комплексно та отримати цілісну картину про проблему та контекст, у якому вона виникла та набула свого розвитку.

Методологічний потенціал трансдисциплінарності у процесі підготовки майбутніх моряків ґрунтується на нових способах організації досліджень, які виходять за межі окремих дисциплін та потребують залучення позадисциплінарного знання; врахуванні ціннісних та цільових сторін поставленого практичного завдання, необхідності формулювання проблемних запитань; використанні евристичного потенціалу, який сприяє трансдисциплінарному вирішенню поставленого практичного завдання; необхідність формування нових організаційних груп («трансдисциплінарні колективи»), у яких методи та способи розв'язання поставленого завдання формуються та коректуються у процесі роботи (Киященко\&Гребенщикова, 2011). 
Ураховуючи особливості трансдисциплінарного підходу до організації освітнього процесу майбутніх моряків, можна стверджувати, що зазначений підхід надає широкі можливості для формування та розвитку природничоматематичної компетентності фахівців. Аналіз наукових доробок вітчизняних та зарубіжних науковців засвідчив, що поняття «компетентність» не $€$ новим. Проте, у літературі зустрічаються різні підходи до класифікації компетентностей, їх кількості та переліку, якими повинен володіти фахівець морської галузі. Зокрема, О.Аверіна, Е.Башкаєва, Ю.Колягіна, О.Тамер у своїх працях розглядають поняття «математична компетентність»; Т.Засєкіна, В.Заболотний, Н.Сосницька, О.Пінчук, М.Шут вивчали дефініцію «фізична компетентність»; О.Легкий, М.Граб, О.Грошовенко, В.Мелаш у своїх доробках розкривали поняття «природнича компетентність»; С.Раков, Н.Баловсяк, М.Головань, Н.Морзе, О.Кузьмінська досліджували поняття «інформатична компетентність». Ми погоджуємося із тим, що набуття кожної із зазначених компетентностей $€$ важливим і необхідним для майбутніх фахівців морського профілю. Проте, враховуючи сучасні тенденції в освіті, зокрема, інтеграцію дисциплін та трансдисциплінарний підхід, вважаємо доцільним формувати та сприяти розвитку саме природничо-математичної компетентності. У своєму дослідженні ми розглядаємо природничоматематичну компетентність як інтегровану якість особистості, яка передбачає володіння знаннями, уміннями, навичками та способами діяльності у галузі математики, інформатики та фізики і виявляється в готовності та здатності особистості використовувати природничо-математичні знання для есективного розв'язання завдань практичного та прикладного змісту.

Оскільки природничо-математична компетентність $€$ складною інтегративною педагогічною категорією, їі необхідно розглядати з позиції системного підходу і виділити відповідні структурні компоненти. Різноманітні підходи до визначення структури компетентності розглянуті у роботі вітчизняних науковців, зокрема, структурні компоненти та функції компетентності (Головань, 2008), компоненти компетентності- змістовий, діяльнісний, особистісний (Шарко, 2006), досвідно-діяльнісна модель компетентності (Коробова, 2013) та ін. У нашій роботі вважаємо доцільним у структурі природничо-математичної компетентності виділити три складові: когнітивну, діяльнісну та особистісну. Врахувавши доробки науковців, нами був розкритий зміст кожного структурного компоненту природничо-математичної компетентності (рис. 1).

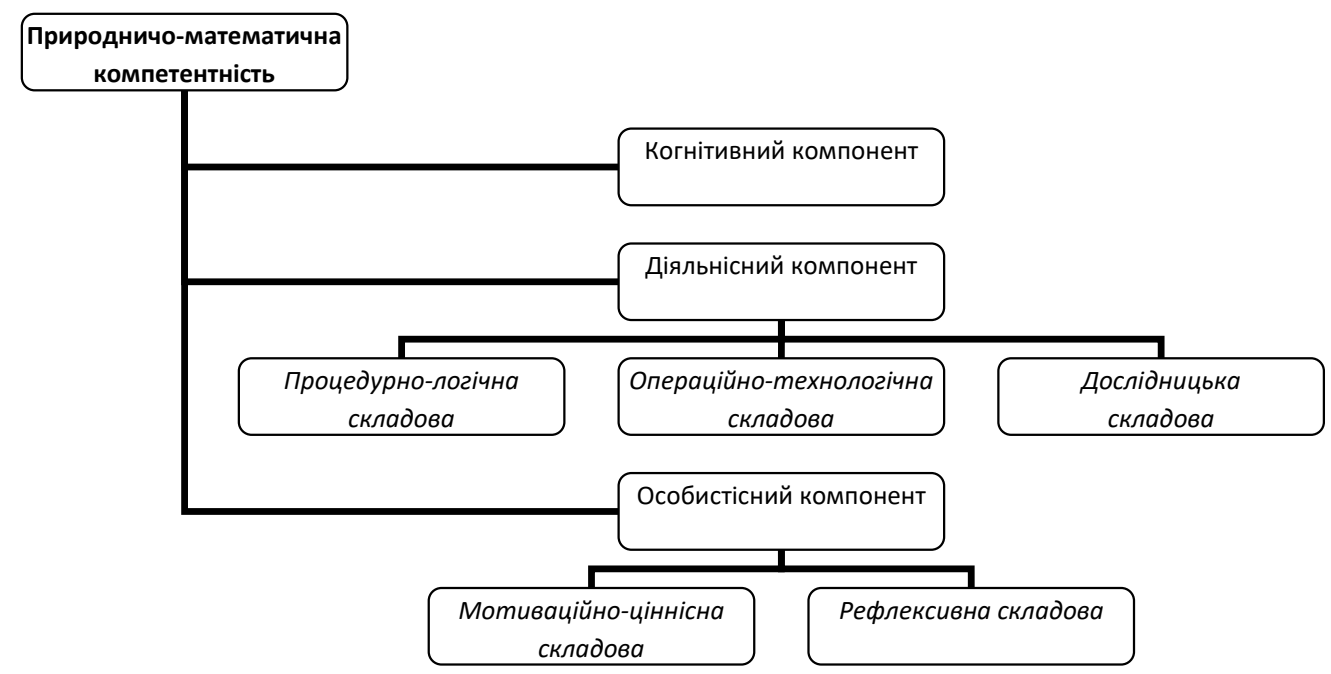

Рис. 1. Структура природничо-математичної компетентності

Когнітивний компонент природничо-математичної компетентності включає сукупність знань з математики, фізики та інформатики теоретичного і практичного характеру, що відображають систему сучасної математики.

Діяльнісний компонент включає процедурно-логічну, операційно-технологічну та дослідницьку складові. Прочедурно-логічна складова діяльнісної компоненти передбачає оволодіння комплексом математичних умінь (аналітичних, обчислювальних, алгоритмічних, функціональних, геометричних, стохастичних, ймовірнісних, математичного моделювання); використання на практиці алгоритмів розв'язування типових задач; володіння дедуктивним методом доведення та спростування тверджень; фізичних умінь (пояснювати фізичні явища, роботу техніки та механізмів, застосовувати фізичні закони та формули при розв'язуванні фізичних задач); уміння з інформатики (використовувати засоби інформаційних технологій для пошуку та систематизації інформації, програмні продукти при розв'язанні математичних та фізичних задач, будувати алгоритми розв'язування задач, візуалізувати отриманий результат).

Операчійно-технологічна складова передбачає формування та розвиток у здобувачів умінь використовувати набуті знання та специфічні уміння з математики, фізики та інформатики, а також готовність застосовувати їх для розв'язування практичних, прикладних та професійних завдань.

Дослідницька складова передбачає володіння методами дослідження соціально та індивідуально значущих завдань за допомогою інформаційно-комунікаційних технологій і математичних методів (формулювати математичні задачі на основі аналізу соціально та індивідуально значущих задач; будувати аналітичні та інформаційні моделі задач; інтерпретувати результат, отриманий формальним методом, у термінах вихідної предметної області; систематизувати отримані результати). 
Особистісний компонент включає мотиваційно-ціннісну та рефлексивну складові. Мотиваційно-ціннісна складова передбачає мотивацію та ставлення (цінності та інтереси) до діяльності з використанням знань з математики, фізики та інформатики; саме вони забезпечують застосування набутих знань для розв'язку проблем. Даний компонент характеризується системою орієнтацій майбутнього фахівця на розуміння та вільне оперування здобутими знаннями та вміннями (з математики, фізики та інформатики), на самостійний пошук необхідних знань, перенесення відомих способів діяльності в нові, нестандартні ситуації, прояв активності судження, критичності мислення, гнучкості методу, прогнозування власної діяльності - розвиток творчого потенціалу особистості. Рефлексивна складова характеризує самоконтроль, самоаналіз та самооцінку здобувача освіти.

Результати досліджень науковців свідчать про значні переваги побудови освітнього процесу на засадах компетентнісного підходу перед традиційним (Коробова, 2017; Шарко, 2006). Зокрема, при постановці перед здобувачами завдання компетентнісного характеру його вирішення передбачає самостійний цільовий пошук необхідних відомостей та формування алгоритму виконання поставленого завдання. У задачах такого типу основним продуктом $\epsilon$ свідоме засвоєння здобувачами знань та умінь формувати стратегію розв'язування компетентнісних задач, планувати процес їх розв'язання, робити аналіз отриманих результатів, шукати та виправляти допущені помилки. Залучення курсантів до розв'язування завдань компетентнісного характеру сприятиме їх інтелектуальній активності та самостійності, формуванню здатності до цілепокладання, оцінювання, ефективної дії та рефлексії (Морзе, Кузьмінська, Вембер, Барна, 2010). Використання трансдисциплінарного підходу при складанні компетентнісних задач надає широкі можливості залучити майбутніх фахівців до розв'язування саме практичних завдань, які наближені до професійної діяльності майбутніх моряків. На думку А. Хуторського до компетентнісних необхідно відносити такі завдання, при вирішенні яких у здобувачів формується розуміння теоретичних основ виконуваної або проектованої діяльності, формуються базові уміння та навички, здатність поєднувати теорію та практику, уміння користуватися письмовими, усними та інформаційними засобами комунікації (Хуторський\&Хуторская, 2008). При цьому, компетентнісні задачі допомагають сприйняти та зрозуміти навчальний матеріал і передбачають: змістовний аналіз формулювання задачі, побудову інформаційної моделі, розробку стратегії пошуку інформаційних матеріалів, опрацювання даних та подання результатів розв'язування задачі (Войтків, 2016). Прикладом компетентнісно орієнтованих завдань для школярів є завдання, які пропонує Міжнародна програма оцінювання навчальних досягнень учнів у сфері функціональної грамотності.

У своїх дослідженнях Л. Павлова визначає вимоги до компетентнісних задач, а саме: можуть мати декілька способів розв'язування; передбачають комплексне використання предметних знань з різних дисциплін, умови яких пов'язані з професійною діяльністю/ з реальними життєвими ситуаціями (Павлова, 2009). При цьому Л. Павлова зазначає, що компетентнісна задача повинна відповідати хоча б одній із наведених вимог.

У ході дослідження нами були підібрані та адаптовані до навчання майбутніх моряків компетентнісні завдання у межах трансдисциплінарного підходу, використання яких сприятиме формуванню природничо-математичної компетентності майбутніх моряків. Розглянемо приклад такого завдання.

Компетентнісна задача. Для уникнення зіткнення, капітан судна приймає рішення про здійснення аварійного маневру «Покладання руля на правий борт з повним реверсним рухом (рух назад)». Рух судна на площині задано двома рівняннями руху $x=4 t$ та $y=16 t^{2}-1$ (усм). Момент часу $t=\frac{1}{2} c$. Визначити вигляд траєкторії. Для моменту часу $\mathrm{t}$ знайти кінематичні характеристики судна, положення судна на траєкторії, його швидкість, повне, нормальне та дотичне прискорення, а також радіус викривлення траєкторії в даній точці.

Методичні особливості задачі. Запропонована курсантам морського профілю задача має компетентнісний характер, оскільки - безпосередньо пов'язана з їх майбутньою професійною діяльністю; у задачі наведений реальний (корисний) для здобувачів факт; зміст задачі створює ситуацію «присутності» курсантів у реальних умовах; вирішення даної задачі передбачає використання курсантами набутих знань з фізики (зокрема таких понять: траєкторія, швидкість, прискорення (нормальне та дотичне), радіус кривизни траєкторії), математики (розв'язування лінійних та квадратичних рівнянь, використання методу заміни при розв'язуванні рівнянь, побудова графіку для визначення вигляду траєкторії, координати точки на площині, виконання простих математичних дій) та інформатики (для побудови графіку залежності $y=x(t)$, а також виконання розрахунків, доцільно використати MO Excel або он-лайн платформу GeoGebra). Hеобхідно також зазначити, що використання компетентнісних задач $€$ ефективним саме на інтегрованих уроках - найдоцільнішій формі організації освітнього процесу в умовах реалізації трансдисциплінарного підходу.

\section{ВИСНОВКИ ТА ПЕРСПЕКТИВИ ПОДАЛЬШОГО ДОСЛІДЖЕННЯ}

У ході дослідження було встановлено, що у процесі підготовки майбутніх фахівців морського напряму доцільним $\epsilon$ впровадження в освітній процес трансдисциплінарного підходу, який дозволяє розглянути проблему з позиції декількох дисциплін. При цьому, отримані трансдисциплінарні знання дозволяють не тільки розв'язувати практичні завдання, а й формувати здатність у особистості до їх продукування. Використання в освітньому процесі підготовки майбутніх моряків трансдисциплінарного підходу надає можливість формувати та розвивати природничо-математичну компетентність майбутніх фахівців, яка $є$ складною педагогічною категорією і представляє собою інтегровану якість особистості, яка передбачає не тільки володіння знаннями, уміннями, навичками та способами діяльності у галузі математики, інформатики та фізики, а й виявляється в готовності та здатності особистості використовувати природничо-математичні знання для ефективного розв'язання завдань практичного/прикладного та професійного змісту. Розглядаючи природничо-математичну компетентність з позиції системного підходу було виділено три компоненти: когнітивний, діяльнісний та особистісний (останні два також мають складну структуру). Одним із шляхів формування природничоматематичної компетентності майбутніх моряків $\epsilon$ залучення їх до виконання завдань компетентнісного характеру, які передбачають самостійний цільовий пошук здобувачами необхідних відомостей та формування алгоритму виконання поставленого завдання. 
Досвід впровадження компетентнісних завдань в освітній процес підготовки майбутніх моряків дає підстави стверджувати, що вони є ефективним засобом формування природничо-математичної компетентності, сприяють розвитку інтелектуальної активності та самостійності здобувачів, підвищення зацікавленості до вивчення фізики, математики та інформатики. Дослідження варто продовжити у напрямку конструювання компетентнісних завдань та їх впровадження у процес навчання курсантів.

\section{Список використаних джерел}

1. Кушнір О.В. Проблема трансдисциплінарного підходу у українській системі вищої освіти. Знання. Освіта. Освіченість, 2018. URL: https://conferences.vntu.edu.ua/index.php/znanosv/znanosv2018/paper/view/5996 (Дата звернення 07.07.2021).

2. Mittelstraß J. Transdisciplinarity - New Structures in Science. Innovative Structures in Basic Research (Ringberg, 4-7 October, 2000). Max-PlanckGesellschaft, 2000. S. 43-54.

3. Киященко Л.П., Моисеев В.И. Философия трансдисциплинарности. Москва: ИФ РАН, 2009. 205 с.

4. Transdisciplinarity: Stimulating Synergies, Integrating Knowledge Division of Philosophy and Ethics UNESCO. 1998. P. 37-38. URL: http://unesdoc.unesco.org/images/0011/001146/ 114694eo.pdf (Дата звернення 05.07.2021).

5. Савков А. П. Трансдисциплінарний підхід як інноваційна технологія підготовки фахівців у галузі публічного управління. Матеріали щорічної науково-практичної конференції «Актуальні питання підготовки фахівців у срері публічного управління та адміністрування» (Київ, 1-2 листопада 2018 р.). НАДУ, 2018. С. 156.

6. Ганаба С. Методологічний потенціал трансдисциплінарного підходу в організації змісту навчання. Наукові записки Національного університету Острозька академія. Серія: Філософія, 2014. Випуск 15. С. 62-67.

7. Киященко Л.П., Гребенщикова Е.Г. Современная философия науки: трансдисциплинарные аспекты. Москва: МГМОУ, 2011. $146 \mathrm{c}$.

8. Головань М.С. Компетенція і компетентність: досвід теорії, теорія досвіду. Вища освіта України. 2008. №3. С. 23-30. URL: https://core.ac.uk/download/pdf/324272272.pdf (Дата звернення 02.08.2021)

9. Шарко В.Д. Методична підготовка вчителя фізики в умовах неперервної освіти: Монографія. Херсон: Вид-во ХДУ, 2006. $400 \mathrm{c.}$

10. Коробова І.В. Досвідно-діяльнісна модель методичної компетентності вчителя фізики. Вісник Чернігівського нац. пед. ун-ту : Серія : Педагогічні науки. Чернігів : ЧНПУ, 2013.Вип. 109. С. 185-189.

11. Коробова І.В. Формування методичної компетентності майбутніх учителів фізики на засадах індивідуального підходу: автореф. дис. ... докт. пед. наук; спец. 13.00.02 - теорія та методика навчання (фізика). - Херсон: ФОП Грінь Д.С., 2017. $40 \mathrm{c}$.

12. Морзе Н.В., Кузьмінська О.Г., Вембер В.П., Барна О.В Компетентнісні завдання як засіб формування інформатичної компетентності у умовах неперервної https://elibrary.kubg.edu.ua/id/eprint/901/1/N_Morze_O_Kuzminska_V_Vember_O_Barna_ITO_4.pdf (Дата звернення 09.07.2021)

13. Хуторской А.В., Хуторская Л.Н. Проектирование и организация самостоятельной работы студентов в контексте компетентностного подхода: Межвузовский сборник научных трудов. 2008. Выпуск 1. С.117-137.

14. Войтків Г. Компетентнісні задачі з фізики. Фізика. Технології. Навчання, 2016. Випуск 14. С. 45-49.

15. Павлова Л.В. Познавательные компетентностные задачи как средство формирования предметно-профессиональной компетентности будущего учителя математики. https://lib.herzen.spb.ru/media/magazines/contents/1/113/pavlova_113_169_174.pdf (Дата звернення 07.07.2021).

16. Мищик С.А. (2015). Системные задачи статической прикладной физики морского флота. URL: https://infourok.ru/sistemnie-zadachi-po-staticheskoy-prikladnoy-morskoy-fizike-1662697.html (Дата обращения 12.08.2020).

\section{References}

1. Kushnir O.V. (2018). Problema transdystsyplinarnoho pidkhodu u ukrainskii systemi vyshchoi osvity [The problem of transdisciplinary approach in the Ukrainian higher education system]. Znannia. Osvita. Osvichenist. Retrieved from https://conferences.vntu.edu.ua/index.php/znanosv/znanosv2018/paper/view/5996 [in Ukrainian].

2. Mittelstraß J. Transdisciplinarity (2000). New Structures in Science. Innovative Structures in Basic Research (Ringberg, 47 October, 2000). Max-PlanckGesellschaft, 43-54.

3. Kiyashchenko L.P., Moiseyev V.I. (2009). Filosofija transdisciplinarnosti [Philosophy of transdisciplinarity]. Moskva: IF RAN, 205 [in Russian].

4. Transdisciplinarity: Stimulating Synergies, Integrating Knowledge Division of Philosophy and Ethics UNESCO. 1998. P. 37-38. Retrieved from http://unesdoc.unesco.org/images/0011/001146/114694eo.pdf [in English].

5. Savkov A.P. (2018). Transdystsyplinarnyi pidkhid yak innovatsiina tekhnolohiia pidhotovky fakhivtsiv u haluzi publichnoho upravlinnia [Transdisciplinary approach as an innovative technology for training specialists in the field of public administration]. Proceedings from Materialy shchorichnoi naukovo-praktychnoi konferentsii «Aktualni pytannia pidhotovky fakhivtsiv u sferi publichnoho upravlinnia ta administruvannia»(pp. 156). NADU [in Ukrainian].

6. Hanaba S. (2014). Metodolohichnyi potentsial transdystsyplinarnoho pidkhodu v orhanizatsii zmistu navchannia [Methodological potential of transdisciplinary approach in the organization of learning content]. Naukovi zapysky Natsionalnoho universytetu Ostrozka akademiia. Seriia: Filosofiia, 15, 62-67 [in Ukrainian].

7. Kijashhenko L.P., Grebenshhikova E.G. (2011). Sovremennaja filosofija nauki: transdisciplinarnye aspekty [Modern philosophy of science: transdisciplinary aspects]. Moskva: MGMOU [in Russian]. 
8. Holovan' M.S. (2008). Kompetentsiya i kompetentnist': dosvid teoriyi, teoriya dosvidu [Competence and competence: experience of theory, theory of experience]. Vyshcha osvita Ukrayiny, 3, 23-30. Retrieved from https://core.ac.uk/download/pdf/324272272.pdf [in Ukrainian].

9. Sharko V.D. (2006). Metodychna pidhotovka vchytelya fizyky v umovakh neperervnoyi osvity [Methodical training of a physics teacher in the conditions of continuous education]: Monohrafiya. Kherson: Vyd-vo KHDU, 400 [in Ukrainian].

10. Korobova I.V. (2013). Dosvidno-diyal'nisna model' metodychnoyi kompetentnosti vchytelya fizyky [Activity experience` model of methodical competence of a physics teacher]. Visnyk Chernihivs'koho nats. ped. un-tu : Seriya : Pedahohichni nauky. Chernihiv: CHNPU, 109, 185-189 [in Ukrainian].

11. Korobova I.V. (2017). Formuvannya metodychnoyi kompetentnosti maybutnikh uchyteliv fizyky na zasadakh indyvidual'noho pidkhodu [Formation of methodical competence of future teachers of physics on the basis of individual approach]: avtoref. dys. ... dokt. ped. nauk; spets. 13.00.02 - teoriya ta metodyka navchannya (fizyka). Kherson: FOP Hrin' D.S., 40 [in Ukrainian].

12. Morze N. V., Kuz'mins'ka O.H., Vember V.P., Barna O.V (2010). Kompetentnisni zavdannia yak zasib formuvannia informatychnoi kompetentnosti $v$ umovakh neperervnoi osvity [Competence tasks as a means of forming information competence in the context of continuing education]. Retrieved from http://www. nbuv. gov. ua/portal/Soc_Gum/itvo/2010_6/2. Pdf [in Ukrainian].

13. Hutorskoj A.V., Hutorskaja L.N. (2008). Proektirovanie i organizacija samostojatel'noj raboty studentov v kontekste kompetentnostnogo podhoda [Designing and organizing independent work of students in the context of the competence approach]. Mezhvuzovskij sbornik nauchnyh trudov - Interuniversity collection of scientific works, 1, 117-137 [in Russian].

14. Voitkiv H. (2016). Kompetentnisni zadachi z fizyky [Competence tasks in physics]. Fizyka. Tekhnolohii. Navchannia, 14, 45-49 [in Ukrainian].

15. Pavlova L.V. (2009). Poznavatel'nye kompetentnostnye zadachi kak sredstvo formirovanija predmetno-professional'noj kompetentnosti budushhego uchitelja matematiki [Cognitive competence tasks as a means of forming the subjectprofessional competence of the future teacher of mathematics]. Retrieved from https://lib.herzen.spb.ru/media/magazines/contents/1/113/pavlova_113_169_174.pdf [in Russian].

16. Mishchik S.A. (2015). Sistemnyye zadachi staticheskoy prikladnoy fiziki morskogo flota [Systemic tasks of static applied physics of the marine fleet.]. (n.d.) infourok.ru Retrieved from https://infourok.ru/sistemnie-zadachi-po-staticheskoy-prikladnoymorskoy-fizike-1662697.html [in Russian].

\section{IMPLEMENTATION OF TRANSDISCIPLINARY APPROACH AS A MEANS OF FORMATION OF NATURAL AND MATHEMATICAL COMPETENCE OF FUTURE SEAMEN \\ Olena Plotnikova \\ Kherson Maritime College of Fishing Industry, Ukraine \\ Iryna Korobova \\ Kherson State University, Ukraine}

Abstract. Modern Ukrainian education is in the process of reform. Oversaturation of the labor market with humanitarian specialists does not contribute to the active development of the economic sector of our country. That is why the Ministry of Education and Science of Ukraine shifts the emphasis from the disciplines of the humanities to the disciplines of the natural and mathematical cycle. At the same time, in the process of professional activity, specialists in all fields (including maritime) face problems, the solution of which requires interdisciplinary knowledge, ie, they need to show their competence. The basis for the training of such specialists is the introduction of a transdisciplinary approach into the educational process, which today is a necessary condition for the development of education in general. In addition, the implementation of a transdisciplinary approach provides an opportunity to intensify the cognitive activity of applicants, promotes the formation of their professional qualities, in particular, natural and mathematical competence.

Problem formulation. The purpose of the article is to analyze the features of the transdisciplinary approach and identify opportunities for its implementation in the process of forming the natural and mathematical competence of future sailors.

Materials and methods. Theoretical and empirical research methods are used in the work, such as analysis of literature sources, synthesis, observation of the educational process, systematization and generalization of research results.

Results. The paper presents an example of a competency task constructed within a transdisciplinary approach. The experience of using competence tasks in the training of future seafarers has proved their effectiveness, as they provide ample opportunities to involve future professionals in solving practical problems close to the professional activities of future seafarers, which in turn contributes to the formation of their natural and mathematical competence.

Conclusions. It is proved that the transdisciplinary approach is relevant today and provides ample opportunities for teachers to achieve the goals of the educational process. In addition to the fact that a transdisciplinary approach is a necessary condition for the development of modern education, it is also a guarantee of successful formation of natural and mathematical competence of future sailors, which requires the applicant to demonstrate integrated knowledge of mathematics, physics and computer science in solving professional problems. One of the ways to implement a transdisciplinary approach in the educational process is to involve applicants in solving competency problems.

Keywords: transdisciplinary approach, natural-mathematical competence, competence task, educational process.

\section{(cc) BY-NC-sA}

This work is licensed under Creative Commons Attribution-NonCommercial-ShareAlike 4.0 International License. 